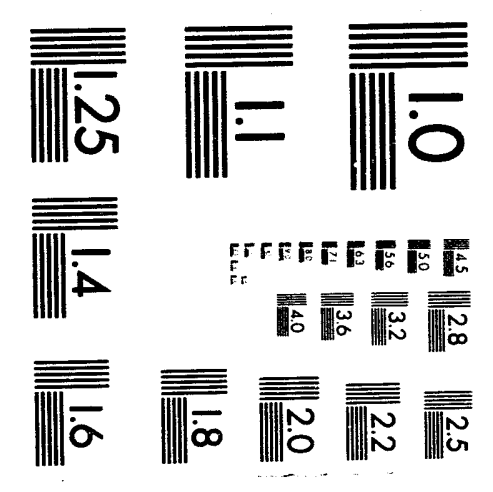



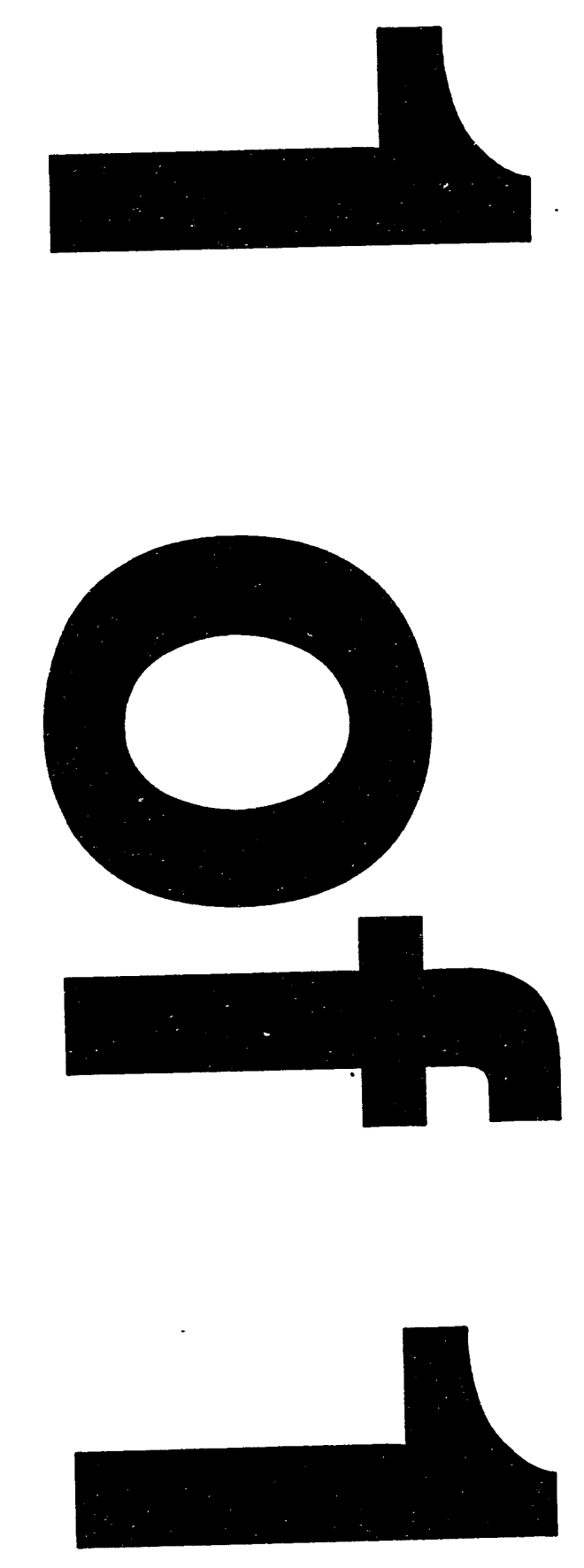


\title{
Identification of Permit and Waste Acceptance Criteria Provisions Requiring Modification for Acceptance of Commercial Mixed Waste
}

\author{
Published March 1994 \\ DISCLAIMER
}

\begin{abstract}
This report was prepared as an account of work sponsored by an agency of the United States Government. Neither the United States Government nor any agency thereof, nor any of their employees, makes any warranty, express or implied, or assumes any legal liability or responsibility for the accuracy, completeness, or usefulness of any information, apparatus, product, or process disclosed, or represents that its use would not infringe privately owned rights. Reference herein to any specific commercial product, process, or service by trade name, trademark, manufacturer, or otherwise does not necessarily constitute or imply its endorsement, recommendation, or favoring by the United States Government or any agency thereof. The views and opinions of authors expressed herein do not necessarily state or reflect those of the United States Government or any agency thereof.
\end{abstract}

\section{Idaho National Engineering Laboratory \\ EG\&G Idaho, Inc. \\ Idaho Falls, Idaho 83415}

Prepared by Ebasco Environmental for EG\&G Idaho, Inc.

Under Subcontract No. C-90-132744

and for the

U.S. Department of Energy

Under DOE Idaho Operations Office

Contract DE-AC07-761001570 


\section{CONTENTS}

ACRONYMS AND ABBREVIATIONS $\ldots \ldots \ldots \ldots \ldots \ldots \ldots \ldots \ldots \ldots \ldots, \ldots \ldots, \ldots \ldots$

1. INTRODUCTION $\ldots \ldots \ldots \ldots \ldots \ldots \ldots \ldots \ldots \ldots \ldots \ldots \ldots \ldots \ldots \ldots$

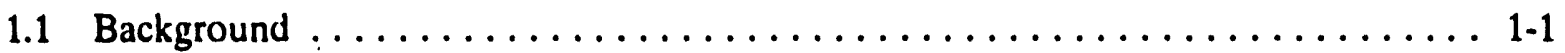

1.2 Methodology $\ldots \ldots \ldots \ldots \ldots \ldots \ldots \ldots \ldots \ldots \ldots \ldots \ldots \ldots \ldots \ldots \ldots \ldots \ldots$

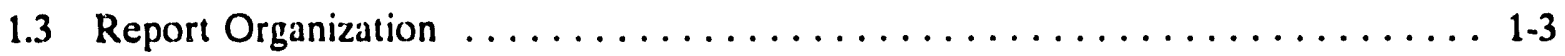

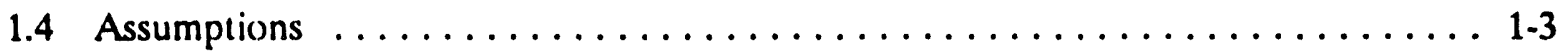

2. FACILITY PERMIT AND WASTE ACCEPTANCE CRITERIA

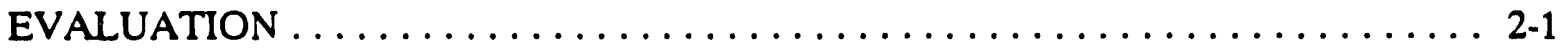

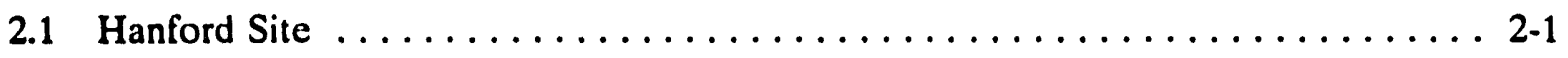

2.1.1 Disposal Facility Summary .................... 2-1

2.1.2 Summary of Permit and WAC Provisions Relating to Acceptance of Mixed Waste for Disposal . . . . . . . . . . . . . . 2-2

2.2 Idaho National Engineering Laboratory $\ldots \ldots \ldots \ldots \ldots \ldots \ldots \ldots \ldots \ldots$

2.2.1 Disposal Facility Summary . . . . . . . . . . . . . . .

2.2.2 Summary of Permit and WAC Provisions Relating to Acceptance of Mixed Waste for Disposal . . . . . . . . . . . . . .

2.3 Los Alamos National Laboratory . . . . . . . . . . . . . .

2.3.1 Disposal Facility Summary . . . . . . . . . . . . . . 2-4

2.3.2 Summary of Permit and WAC Provisions Relating to Acceptance of Mixed Waste for Disposal . . . . . . . . . . . . . . 2-4

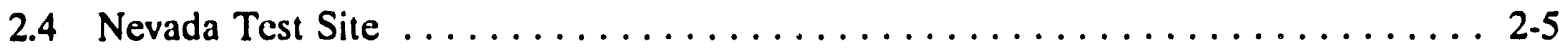

2.4.1 Disposal Facility Summary .................... 2-5

2.4.2 Summary of Permit and WAC Provisions Relating to Acceptance of Mixed Waste for Disposal . . . . . . . . . . . . .

2.5 Oak Ridge National Laboratory $\ldots \ldots \ldots \ldots \ldots \ldots \ldots \ldots \ldots \ldots \ldots \ldots$

2.5.1 Disposal Facility Summary .................... 2-6

2.5.2 Summary of Permit and WAC Provisions Relating to Acceptance of Mixed Waste for Disposal . . . . . . . . . . . . . . 6 
2.6 Savannah River Site

2.6.1 Disposal Facility Summary

2.6 .2 Summary of Permit and WA

3. CONCLUSIONS AND SUMMARY 3-1

4. REFERENCES 4-1

\section{TABLES}

3-1. DOE mixed waste facility status

$3-2$ 


\section{ACRONYMS AND ABBREVIATIONS}

$\begin{array}{ll}\text { DOE } & \text { U.S. Department of Energy } \\ \text { DOE/NV } & \text { U.S. Department of Energy, Nevada } \\ \text { ER } & \text { Environmental Restoration (Unit) } \\ \text { INEL } & \text { Idaho National Engineering Laboratory } \\ \text { LANL } & \text { Los Alamos National Laboratory } \\ \text { LLW } & \text { low-level radioactive waste } \\ \text { MWDU } & \text { mixed waste disposal unit } \\ \text { NA } & \text { not applicable } \\ \text { NBFF } & \text { Bureau of Federal Facilities (Nevada) } \\ \text { NEPA } & \text { National Environmental Policy Act } \\ \text { NTS } & \text { Nevada Test Site } \\ \text { NTS WAC } & \begin{array}{l}\text { Nevada Test Site Defense Waste Acceptance Criteria, Certification, and } \\ \text { Transfer Requirements }\end{array}\end{array}$

ORNL

Oak Ridge National Laboratory

RCRA

Resource Conservation and Recovery Act

RMW

radioactive mixed waste

RWMC

Radioactive Waste Management Complex

SHWO WAC

Savannah River Site Waste Acceptance Criteria Manual

SRS

Savannah River Site

SWAC

Hanford Site Solid Waste Acceptance Criteria

SWSA-6

Solid Waste Storage Area 6

TRU

transuranic

TSDF

treatment, storage, and disposal facility 
WAC

WSRC waste acceptance criteria

Westinghouse Savannah River Company 


\section{Identification of Permit and Waste Acceptance Criteria Provisions Requiring Modification for Acceptance of Commercial Mixed Waste}

\section{INTRODUCTION}

\subsection{Background}

In October 1990, representatives of States and compact regions requested that the U.S. Department of Energy (DOE) explore an agreement with host States and compact regions under which DOE would accept commercial mixed low-level radioactive waste (LLW) at DOE's own treatment and disposal facilitics. A program for DOE management of commercial mixed waste is made potentially more attractive in light of the low commercial mixed waste volumes, high regulatory burdens, public opposition to new disposal sites, and relatively high cost of constructing commercial disposal facilities.

Several studies were identified as essential in determining the feasibility of DOE accepting commercial mixed waste for disposal. The purpose of this report is to identify any current or proposed waste acceptance critcria (WAC) or Resource Conservation and Recovery Act (RCRA) provisions that would have to be modified for commercial mixed waste acceptance at specified DOE facilities.

\subsection{Methodology}

To prepare this report, existing WAC and, where available, RCRA permit application documents from the following six DOE sites were reviewed:

- Hanford Site, Washington

- Los Alamos National Laboratory, New Mexico

- Nevada Test Site, Nevada

- Oak Ridge National Laboratory, Tennessee

- Savannah River Site, South Carolina

- Idaho National Engineering Laboratory, Idaho. 
In addition, personnel from the DOE sites, operating contractors, and State environmental agencies were contacted by telephone to compile the following information:

- The opcrational status and schedules for completion of mixed waste disposal facilities at the site

- The mixed waste disposal capacity at the facility, where available

- The status of RCRA Part B permits for mixed waste disposal facilities

- The status of WAC for mixed waste disposal

- Whether offsite generators are authorized to dispose of mixed waste at the site.

The status of the RCRA Part B permits is important because such information will determine how the permit application can be modified (either during the application process or after issuance) if a commercial mixed waste acceptance program is implemented. References regarding the status of Part $B$ permits for each facility will refer to the following permit process stages:

1. The DOE facility submits Part B information to the reviewing agency

2. The agency conducts a completeness review

3. If the application is not complete, a Notice of Deficiency letter is sent to the DOE facility

4. The agency conducts a technical review of the permit application

5. The draft permit is prepared

6. The draft permit is open to public review and comment

7. The final permit is issued.

In addition to the RCRA permit, site-specific WAC documents were reviewed. These documents are developed in fulfillment of DOE Order 5820.2A. "Radioactive Waste Management," and contain criteria relating to the disposal of radioactive, hazardous, and mixed waste.

The evaluation did not reveal any permit provisions or WAC directly relating to acceptance or prohibition of commercial mixed waste. It is assumed that explicit criteria may need to be incorporated into the permit or WAC allowing acceptance of offsite waste. Accordingly, Sections 2 and 3 focus on other provisions that may impact such acceptance, particularly provisions relating to acceptance and disposal of offsite waste. 


\subsection{Report Organization}

Section 2 of this report (a) provides a background summary of existing and proposed mixed waste disposal facilitics at each DOE site, and (b) summarizes the status of any RCRA Part B permit and WAC provisions relating to the disposal of mixed waste, including provisions relating to acceptance of offsite waste.

Section 3 provides overall conclusions regarding the current status and permit modifications that must be implemented in order to grant DOE sites authority under their permits to accept commercial mixed waste for disposal.

Section 4 contains a list of references.

\subsection{Assumptions}

The analysis in this report is based on the following assumptions:

- Decisions regarding DOE management of commercial mixed waste and identification of facilities that may require modification of permits or WAC will be made in conjunction with the development of DOE mixed waste treatment plans. Specifically, the Federal Facility Compliance Act of 1992, Pub. L. 102-386, requires DOE to submit site-specific mixed waste treatment plans to the U.S. Environmental Protection Agency or appropriate State regulatory agency. The Act specifically recognizes that DOE may propose centralized and regionalized treatment facilities in the site-specific plans to provide needed treatment capacity. Draft plans must be submitted by August 1994 and final plans must be submitted by February 1995.

- DOE facilitics will not be required to treat or store untreated commercial mixed waste; only disposal of mixed waste is evaluated.

- Commercial mixed waste resembles a subset of DOE mixed waste (for further information sec Analysis of the Legal, Regulatory, and Technical Issues Associated with DOE Accepting Commercial Mixed Waste, DOE/LLW-110, draft, National Low-Level Waste Management Program, May 1993).

- Political impediments to acceptance of offsite mixed waste can be overcome. 


\section{FACILITY PERMIT AND WASTE ACCEPTANCE CRITERIA EVALUATION}

\subsection{Hanford Site}

\subsubsection{Disposal Facility Summary}

Two mixed waste disposal facilities have been proposed for the Hanford Site in Washington. The first proposed facility is a mixed waste disposal trench that would be located in the LowLevel Burial Grounds in the 200 Area West of the Hanford Site. The trench will have a volume (air space) of $69,000 \mathrm{yd}^{3}$, and will have the capacity to hold approximately 36,00055 -gal drums of mixed waste. Construction is anticipated to begin in late 1993. The new trench will be for the disposal of mixed waste and will be part of the Hanford RCRA sitewide Part B permit pertaining to the Low-Level Burial Grounds.

The Washington State Department of Ecology is currently in the process of reviewing the application for the RCRA Part B permit for the proposed mixed waste disposal trench. The permit application is in the second Notice of Deficiency cycle, and approval to construct the mixed waste trench could be granted by the Department of Ecology in one to one-and-a-half years. $^{b}$

A second mixed waste disposal facility has been proposed by DOE. The project is currently under study and has not yet entered the permitting process. DOE is proposing a design for a multi-trench landfill that would be $4 \mathrm{mi}^{2}$ in size and would be located south of the 200 Areas. WAC are being established; however, the new landfill may become part of a Corrective Action Management Unit and would thus be limited to receipt of onsite remediating waste. ${ }^{c}$

The Hanford Site also has an existing mixed waste landfill in the East and West sections of the 200 Area opcrating under interim status. Mixed waste from laboratories under contract with

a. Personal communication, Moses Jaraysi, Environmental Engineer, Nuclear and Mixed Waste Management Program, Washington State Department of Ecology, June 28, 1993.

b. Personal communication, Moses Jaraysi, Environmental Engineer, Nuclear and Mixed Waste Management Program, Washington State Department of Ecology, June 24, 1993; Toby Michelena, Environmental Supervisor, Technical Assessments/Systems Integration Unit, Nuclear and Mixed 'v'aste Management Program, Washington State Department of Ecology, June 25, 1993.

c. Personal communication, Moses Jaraysi, Environmental Engineer, Nuclear and Mixed Waste Management Program, Washington Statc Department of Ecology, June 24, 1993. 
Richland, as well as U.S. Department of Defense submarine reactor components, are being disposed of in this trench.

\subsubsection{Summary of Permit and WAC Provisions Relating to Acceptance of Mixed Waste for Disposal}

Current disposal at the site is undertaken in accordance with the Hanford Site Solid Waste Acceptance Criteria (SWAC). The Hanford SWAC are under revision, with the revised version expected to be finished in about one year. ${ }^{e}$

Current Hanford SWAC policy generally precludes the Hanford Site from accepting any waste except LLW from offsite generators as follows:

As specificd by DOE Field Office, Richland, only radioactive waste will be accepted from offsite waste generators and then only on a not-to-affect Hanford Site operations basis ... The scope of the manual is limited to radioactive solid waste acceptance criteria and handling requirements of hazardous waste that is generated by Hanford Site generators. ${ }^{1}$

While it appears that no specific WAC have been developed for acceptance of mixed waste, the Hanford SWAC state, however, that:

DOE Field Office, Richland has informed Westinghouse Hanford Company that routine radioactive mixed waste (RMW) shipments will not be accepted from offsite waste generators in the near future. However, DOE Field Office, Richland will accept limited quantitics of selected RMW. Any request for offsite RMW receipt at the Hanford Site must be made through the waste generator's DOE field office. ${ }^{2}$

d. Personal communication, Joe Witczak, Environmental Engineer, Technical Assistance/Systems Integration Unit, Nuclear and Mixed Waste Management Program, Washington State Department of Ecology, June 24, 1993; personal communication, Toby Michelena, Environment: ' 'upervisor, Technical Assessments/Systems Integration Unit, Nuclear and Mixed Waste Management Program, Washington State Department of Ecology, Junc 25, 1993.

e. Personal communication, Ross Potter, Hart Crowser, Richland, Washington, June 23, 1993. 
No final decision has been reached regarding provisions for the acceptance of offsite mixed waste in the RCRA permit applications under review. At present, the waste acceptance provisions in the application do not preclude such acceptance.'

\subsection{Idaho National Engineering Laboratory}

\subsubsection{Disposal Facility Summary}

Currently, no active mixed waste disposal facilities are operating at the Idaho National Engineering Laboratory (INEL). The INEL does, however, accept some mixed waste, in the form of lead shielding, for onsite storage prior to disposal. ${ }^{8}$

Future mixed waste disposal options are being considered under a project titled, "The New Mixed and Low-Level Radioactive Waste Disposal Facility for the INEL." It is funded by DOE and was begun in Fiscal Year 1992, but is not yet a line-item construction project. The project is currently in the preliminary project definition phase. During this preconceptual phase, personnel are identifying need and onsite disposal capability for the development of a new LLW and RCRA-permitted mixed waste disposal facility. The evaluations include scoping and quantifying applicable waste streams, and the waste forms created by treatment processes. Personnel are also considering various disposal facility siting locations at the INEL, as well as performance assessment issues associated with the development of such a facility. ${ }^{\text {h }}$

An alternatives analysis is also in progress as part of the potential INEL mixed waste disposal facility. The alternatives analysis considers options for the disposal of INEL waste onsite or offsite, and will makc a recommendation regarding this issue to DOE. This recommendation could be made in about six months. If the recommendation is to construct the facility at the INEL, then a facility design will be devcloped. Currently, the studies are only considering disposal for onsite waste, and do not address disposal of waste generated offsite. ${ }^{\text {h }}$

\subsubsection{Summary of Permit and WAC Provisions Relating to Acceptance of Mixed Waste for Disposal}

WAC for LLW have bcen established specifying the requirements that waste generators must satisfy to certify LLW for disposal at the Radioactive Waste Management Complex

f. Personal communication, Ross Potter, Hart Crowser, Richland, Washington, June 23, 1993; Moses Jaraysi, Environmental Engineer, Nuclear and Mixed Waste Management Program, Washington State Department of Ecology, June 24, 1993; Joe Witczak, Environmental Engineer, Technical Assistance/Systems Integration Unit, Nuclear and Mixed Waste Management Program, Washington State Department of Ecology, Junc 24, 1993; personal communication, Toby Michelena, Environmental Supervisor, Technical Assessments/Systems Integration Unit, Nuclear and Mixed Waste Management Program, Washington State Department of Ecology, June 25, 1993.

g. Personal communication, Norm Stanley, EG\&G Idaho, Inc., June 24, 1993.

h. Personal communication, Mike Sherick, Project Engineer, The New Mixed and Low-Level Radioactive Waste Disposal Facility for the INEL, June 25, 1993. 
(RWMC). INEL WAC do not authorize disposal of mixed waste at the INEL. The RWMC WAC specifically prohibit the receipt of radioactive mixed waste for disposal at the RWMC. ${ }^{3}$

\subsection{Los Alamos National Laboratory}

\subsubsection{Disposal Facility Summary}

The Los Alamos National Laboratory (LANL) has no mixed waste disposal capacity because disposal of mixed waste is prohibited under LANL WAC provisions. ${ }^{4}$ Currently, mixed waste is sent to a mixed waste storage dome for storage. Tentative plans have been developed for a mixed waste disposal facility at LANL in the late 1990s. The undeveloped 60-acre site would be located in TA-67, in the area of the Pajarito Mesa. Development of the site, however, may be impeded because of endangered species and habitat issues. ${ }^{i}$ Environmental assessments are currently being conducted. . $^{\mathbf{c}}$

The mixed waste disposal unit is currently in the Title I design (preliminary engineering design) phase. The proposed design could accommodate a volume of $375,000 \mathrm{yd}^{3}$ of mixed waste to be disposed of in approximately 15 waste pits. The disposal facility is planned to be funded through the Environmental Restoration (ER) Unit and would be used for waste generated by activities of the ER Unit, such as soil excavated from remediations, or waste from the decommissioning of old buildings. ${ }^{j}$ A decision on whether to accept waste from other onsite laboratory operations in addition to waste generated by the ER Unit is still pending.j

It is anticipated that the RCRA permit application will be submitted in late 1994 to the State of New Mexico. Draft WAC for the proposed facility were developed as part of the safety analysis report; the draft WAC were issued in September 1993. Final construction is scheduled to start by 1996 after appropriate approvals have been obtained and public hearings have been held.

\subsubsection{Summary of Permit and WAC Provisions Relating to Acceptance of Mixed Waste for Disposal}

The LANL WAC do not specifically address the acceptance of offsite-generated mixed waste. However, discussions with site personnel indicate that LANL policy is not to accept waste from offsite generators. These personnel also stated that an informal policy decision has been made by LANL and DOE that offsite waste will not be accepted for disposal at the proposed facility. ${ }^{k}$ Additionally, the $\mathrm{p}$ sblic has been informed by DOE that no offsite waste will be

i. Personal communication, Tom Ribe, Public Affairs Office, Los Alamos National Laboratory, June 24, 1993.

j. Personal communication, Darrell Bultman, Los Alamos National Laboratory, January 14, 1994.

k. Personal communication, Patricia Trujillio-Oviedo, Community Relations Project Leader, Environmental Restoration Program, LANL. 
disposed in the proposed facility. As stated above, it is presently undecided whether operational waste will be disposed of.

\subsection{Nevada Test Site}

\subsubsection{Disposal Facility Summary}

In the past, the Area 5 Radioactive Waste Management Site of the Nevada Test Site (NTS) received mixed wastc from DOE facilities ant other Federal agencies. This waste was disposed of in mixed waste cell PO3U (Pit 3), which was operating under interim status provisions. ${ }^{\mathrm{m}}$ Approximately 1,072,456 $\mathrm{ft}^{3}$ were previously disposed of in Pit 3 ; the unit is not now accepting waste. Pit 3 has a total capacity of $3,186,797 \mathrm{ft}^{3} .^{\mathrm{n}}$

In addition to Pit 3, a 10-cell double-lined landfill mixed waste disposal unit (MWDU) has been proposed. The proposed MWDU will result in an expansion of the present disposal facilities.

Both Pit 3 and the MWDU will be permitted under the sitewide RCRA permit covering all units; any modifications to individual units will be considered modifications to the general permit. According to personncl from the Nevada Bureau of Federal Facilities (NBFF), the NTS RCRA Part B permit application for the mixed waste landfills received Notices of Deficiency for additional information from the NBFF. The NTS submitted a revised application in 1992, which received a completeness revicw by the NBFF. Currently, the NBFF is conducting a technical review of the application.

\subsubsection{Summary of Permit and WAC Provisions Relating to Acceptance of Mixed Waste for Disposal}

The Nevada Test Site Defense Waste Acceptance Criteria, Certification, and Transfer Requirements ${ }^{5}$ (NTS WAC) provides the requirements, terms, and conditions under which the NTS will accept defense-related LLW and mixed waste for disposal.

The NBFF and DOE have not reached agreement as to whether the RCRA Part B permit will allow the NTS to continue to receive mixed waste from both onsite and offsite generators. The issue may be resolved by litigation because the NBFF is not eager to permit the NTS for

1. Personal communication, Alan McGregor, ERM-C ider, July 1, 1993.

m. Personal communication, Scott Adams, Senior Principal Engineer, Raytheon Co., June 24, 1993.

n. Personal communication, Darwin Morgan, Public Affairs Office, Nevada Test Site, January 18, 1994. 
mixed waste, especially if it were coming from offsite generators. ${ }^{\circ}$ However, DOE desires to use the NTS for system-wide disposal of its waste. ${ }^{p}$ Current NTS WAC policy provides that:

... [i]t is the policy of DOE that waste will be accepted only from gencrators designated by DOE Headquarters and approved by $\mathrm{DOE} / \mathrm{NV}$. All generators will be reviewed for compliance with the requirements of this document, and additional requirements, as may be established by DOE/NV, before receiving approval to ship waste to the NTS. ${ }^{5}$

\subsection{Oak Ridge National Laboratory}

\subsubsection{Disposal Facility Summary}

The Oak Ridge National Laboratory (ORNL) is storing its mixed waste onsite because there are no active mixed waste disposal facilities at ORNL. According to ORNL site personnel and personnel from the Tennessee Department of Environment and Conservation, no mixed waste disposal facilities are planned. It is anticipated that mixed waste will be shipped offsite for disposal. 9 One individual stated that the ORNL site topography and geology likely preclude the disposal of anything but very low-level radioactive waste at the site. ${ }^{r}$

\subsubsection{Summary of Permit and WAC Provisions Relating to Acceptance of Mixed Waste for Disposal}

Solid Waste Storage Area 6 (SWSA-6), a disposal area for radioactive solid and mixed waste, is closing. ORNL WAC state that "only radioactive solid waste meeting the WAC specified in this document is accepted for disposal at SWSA-6. Nonradioactive waste, transuranic (TRU) waste, mixed waste, or radioactive waste will not be accepted."

o. Personal communication, Chuck Bulik, Environmental Engineer, Nevada Bureau of Federal Facilities, DOE Branch, June 23, 1993.

p. Personal communication, Scolt Adams, Senior Principal Engineer, Raytheon Corp., June 24, 1993.

q. Personal communication, Mac Roddye, Program Manager for ORNL DOE Waste Management, June 23, 1993; personal communication, Bob Lenyk, Ebasco Environmental, June 24, 1993; personal communication, Jacquelinc Okorech-Baah, Director, Permitting Section, Division of Solid Waste Management, Tennessec Department of Environment and Conservation, June 24, 1993; personal communication, Tom Scanlon, Section Head, Waste Management Operations, ORNL, June 25, 1993.

r. Personal communication, Mac Rodug, Program Manager for ORNL DOE Waste Management, June 23, 1993.

s. Personal communication, Jacqueline Okoreeh-Baah, Director, Permitting Section, Division of Solid Waste Management, Tennessec Department of Environment and Conservation, June 24, 1993. 
Although ORNL has accepted waste from other DOE sites in the past, site personnel stated that acceptance of waste generated offsite could require the approval of the Tennessee governor.'

\subsection{Savannah River Site}

\subsubsection{Disposal Facility Summary}

The Savannah River Sitc (SRS) is storing its mixed waste onsite because there are no active mixed waste disposal facilitics at the SRS. The SRS is planning to develop hazardous waste/mixed waste disposal vaults. The proposed site is located near the old burial grounds in the E-Area of the SRS.

SRS has submitted a RCRA Part B application for the proposed hazardous waste/mixed waste disposal vaults. The South Carolina Department of Health and Environmental Control reviewed the permit application and issued a Notice of Deficiency in early 1993. The SRS is currently responding to agency comments contained in the Notice of Deficiency. Plans for an additional mixed waste disposal unit in the area are on hold."

\subsubsection{Summary of Permit and WAC Provisions Relating to Acceptance of Mixed Waste for Disposal}

The current Westinghouse Savannah River Company (WSRC)-1S, Savannah River Site Waste Acceptance Criteria Manual (SHWO WAC), precludes the SRS from accepting any waste but LLW from offsite generators. ${ }^{6}$ This policy states:

SRS accepts LLW generated by offsite generators at the LLW E Area Vaults. Other TSDFs do not accept offsite waste without approval from the DOE, appropriate regulatory agencies, and approval of adequate safety and NEPA documentation.

The scope of this section is limited to general and compactible LLW, [onsitc] clean waste, [onsite] TRU waste, [onsite] hazardous waste, [onsite] sanitary waste, and [onsite] mixed waste as accepted at: E Arca Disposal Facility, 643-7E; 253-H Waste Compactor; 642-E Landfill Monitoring Facility; TRU Waste Storage Pads; hazardous waste storage buildings; sanitary waste landfill; and mixed waste storage buildings. ${ }^{7}$

t. Personal communication, Mac Roddye, Program Manager "r DOE Waste Management, ORNL, June 23, 1993.

u. Personal communication, Shelly Sherritt, John Litton, Hazardous Waste Division, South Carolina Department of Health and Environmental Control, June 24, 1993. 
This policy is specilied further in the scope section of the WSRC Solid and Hazardous Waste Operations Gencral Criteria portion and in the purpose and scope sections of the LowLevel Radioactive Solid Wastc Acceptance Criteria for the E Area Waste Disposal Facility portion of the SHWO WAC. ${ }^{6}$ The RCRA permit application waste acceptance provisions under review are consistent with the WAC and do not allow acceptance of offsite waste. 


\section{CONCLUSIONS AND SUMMARY}

The objective of this report was to evaluate current RCRA permit and waste acceptance provisions that may require modification in order to accept commercial mixed waste at DOE sites. The following six DOE sites were evaluated:

- Hanford Sitc

- Idaho National Engineering Laboratory

- Los Alamos National Laboratory

- Nevada Test Sitc

- Oak Ridge National Laboratory

- Savannah River Site.

Table 3-1 provides a summary of the status of the mixed waste facilities discussed in Section 2.

None of the facilitics' permit documents or WAC specifically addressed accepting commercial mixed waste. (As indicated in Section 1, it is assumed that explicit provisions allowing acceptance of commercial mixed waste will have to be included in the permits.) There were, however, provisions and policies authorizing the acceptance of LLW only, or precluding the site from accepting any offsite-generated waste. Personnel that were contacted confirmed that waste generated offsite was subject to restriction or prohibition.

The Hanford Sitc, LANL, NTS, and SRS are planning to develop mixed waste units. The INEL is considering developing a mixed waste disposal facility, but the project is only in the preliminary project delinition phase. ORNL is not planning to develop a facility, but is anticipating offsite disposal for the mixed waste it generates.

Specifically, the Hanliord Site has submitted a RCRA Part B application for the proposed mixed waste disposal units; it is currently under review by the Washington State Department of Ecology. Although no tinal decision has been made, the waste acceptance provisions in the permit application do not specifically preclude acceptance of offsite waste. The Hanford WAC also allow acceptance of of 'fsite mixed waste. Accordingly, no modifications to existing permit language or WAC, beyond explicit provisions relating to commercial mixed waste, should be required.

Design and engincering plans are being developed for the mixed waste disposal facility proposed for LANL, but no per:ait development has started. This mixed waste disposal unit is intended to be used for waste generated onsite by activities of the ER Unit, but not for operational mixed waste. According to site personnel, current policy is to prohibit acceptance of offsite waste. Permit waste acceptance and WAC provisions do not directly address such 
Table 3-1. DOE mixcd waste facility status.

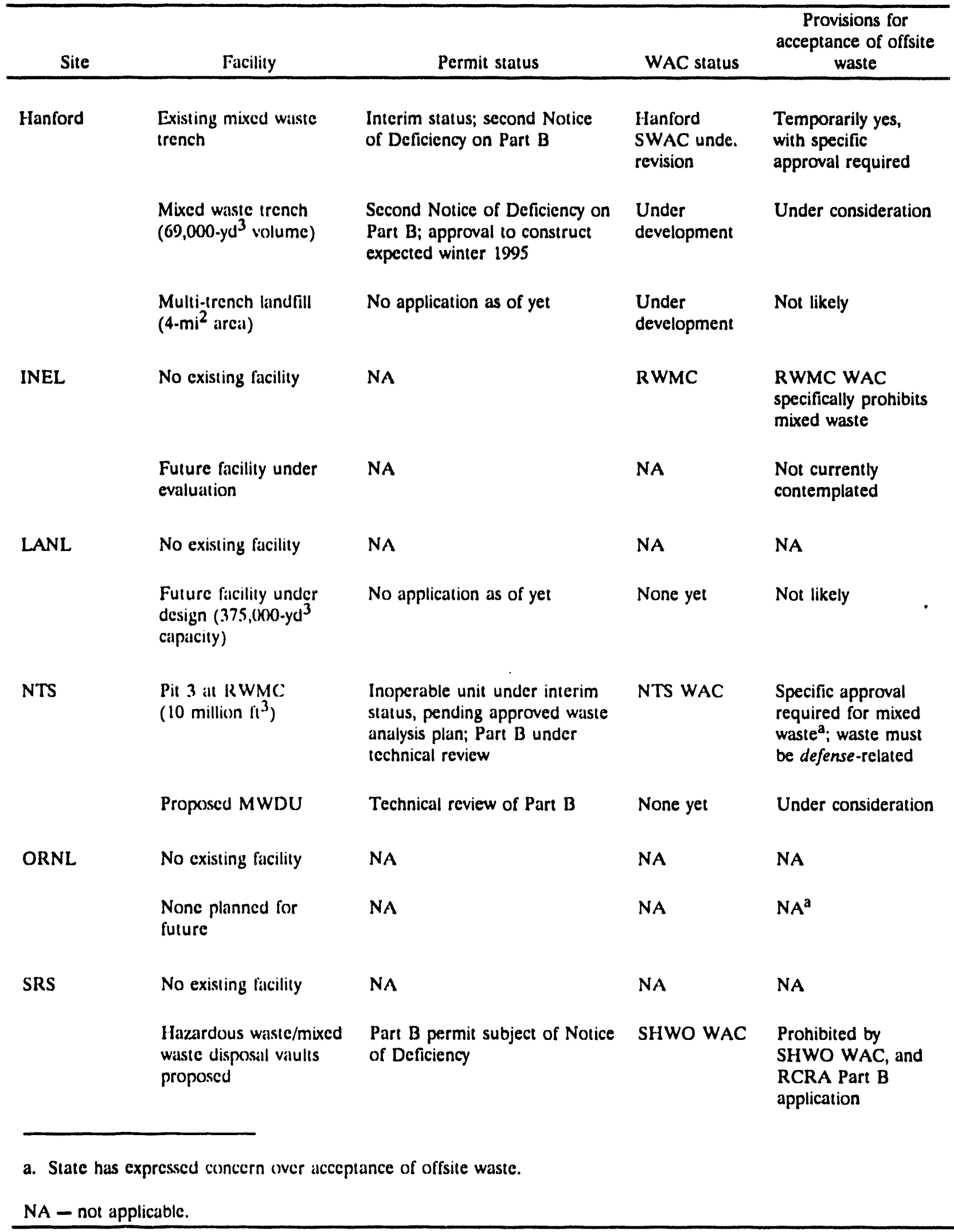


acceptance and would require modilication to allow disposal of oflsite and commercial mixed waste.

The NTS submitted a RCRA Part B permit application to the State for two proposed mixed waste disposal facilitics. Currently, the NBFF is conducting a technical review of the application. NTS is negotiating with the State as to whether the permit will allow acceptance of offsite waste. In addition, present WAC allow only acceptance of defense-related waste. Receipt of commercial mixed waste would require modification of the WAC and applicable permit provisions.

ORNL WAC do not currently allow acceptance of offsite waste, nor are any future mixed waste disposal facilitics planned.

The SRS has applied for a RCRA Part B permit for the proposed hazardous waste/mixed waste disposal vaults. The facility permit application received a Notice of Deficiency in early 1993. Current SRS WAC, as well as waste acceptance provisions in the RCRA permit application, preclude the lacility from accepting any waste but LLW from offsite generators. Both the WAC and the permit thus require modification to all disposal.

The New Mixed and Low-Level Radioactive Waste Disposal Facility for the INEL is in the preliminary project definition phase and has not yet entered the permitting process. The studies for the facility are considering only disposal of onsite waste. It is unclear whether offsite generators would be able to dispose of their waste at the facility. Current WAC do not allow disposal of mixed waste at the site.

In conclusion, the DOE facility RCRA Part B permits, which would contain provisions for mixed waste disposal, are in the application stage and have not been issued for public comment. Accordingly, modifications of the permit to allow acceptance of commercial mixed waste could take place during the application process through agreements with the appropriate permitting authorities. In contrast, modification of permits that have completed the application process and that have been formally issued would have required formal modification procedures and undergone extensive public review and comment. As indicated in Section 1, DOE is now in the process of policy planning for DOE mixed waste disposal and will determine which facilities may be formally designated as disposal sites accepting offsite DOE waste. 


\section{REFERENCES}

1. Hanford Site, Solid Waste Acceptance Criteria, Section 1.1, WHC-EP-0063-3, September 1991.

2. Hanford Site, Waste Acceptance Criteria, Section 2.4, WHC-EP-0063-3, September 1991.

3. EG\&G Idaho, Inc., INEL Low-Level Radioactive Waste Acceptance Criteria: Parts A, B, Section 2.3.1.e, DOE/ID-10112, Rev. 5, October 1992.

4. Los Alamos National Laboratory, Waste Acceptance Criteria for Low-Level Radioactive Waste Disposal at TA.4.3, Area G, Section 4.2.1.4, April 1, 1991.

5. Nevada Test Site Defense Waste Acceptance Criteria, Certification, and Transfer Requirements, Section 1.2, NV0-325, Rev. 1, July 1992.

6. Savannah River Sitc, WSRC-1S, Waste Acceptance Criteria Manual, Waste Acceptance Criteria Program Responsibilities, Scope, WAC 1.01, Rev. 1, February 28, 1993.

7. Savannah River Sitc, WSRC-1S, Waste Acceptance Criteria Manual, Introduction, SRS Waste Management, Solid and Hazardous Waste Operations, Introduction, WAC 3.01, Rev. 0, February 28, 1993. 

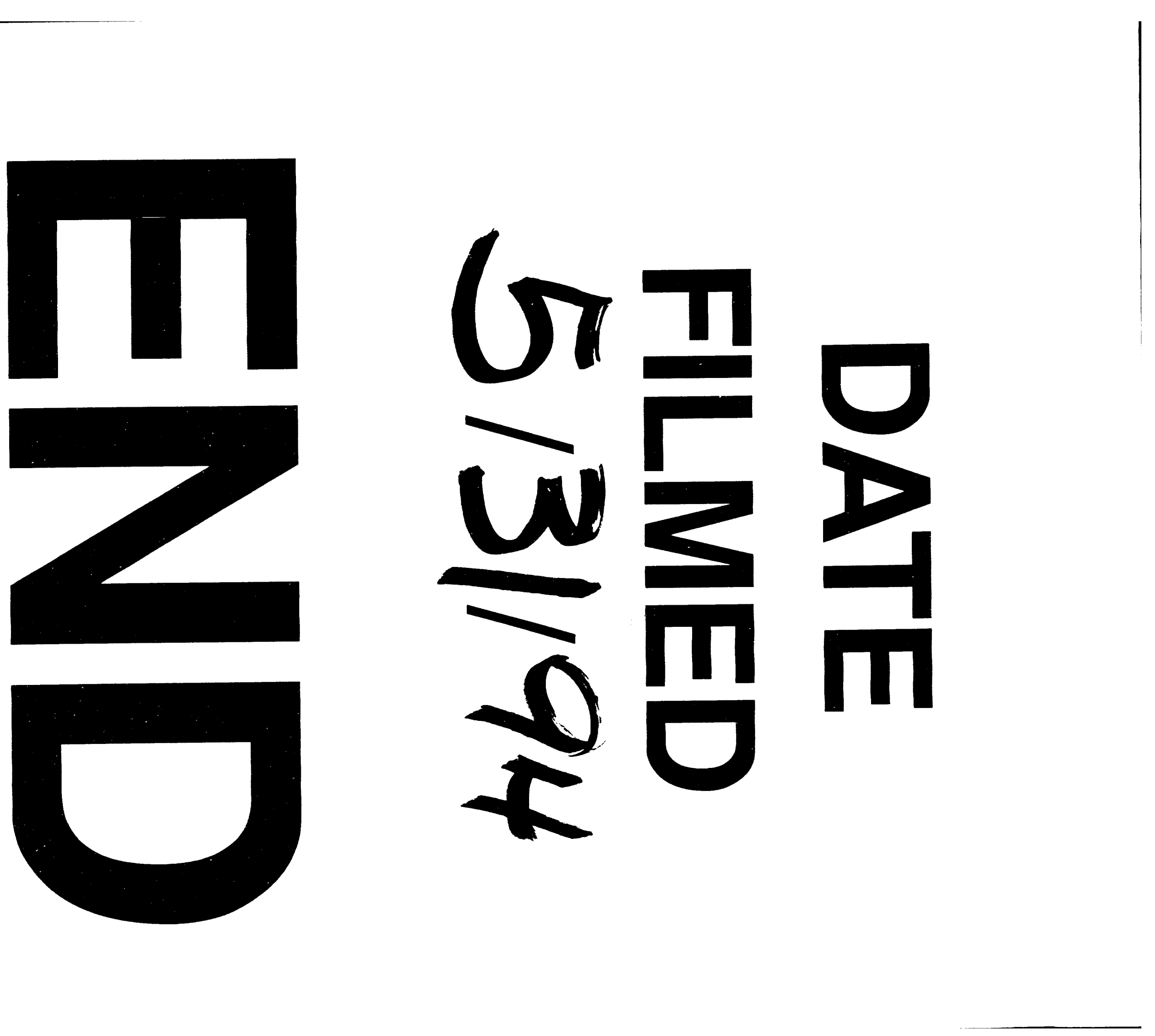
mang nom 